\title{
byg Geológico
}

Boletín Geológico, 48(2), 131-145, 2021

https://doi.org/10.32685/0120-1425/bol.geol.48.2.2021.594

\section{(c) (i)}

This work is distributed under the

Creative Commons Attribution 4.0 License.

Received: May 15, 2020

Revision received: January 30, 2021

Accepted: July 21, 2021

Published online: November 22, 2021
Seismic hazard assessment of the urban area of Ambato, Ecuador, in deterministic form

\author{
Evaluación de la peligrosidad sísmica del área urbana \\ de Ambato, Ecuador, en forma determinística
}

\section{Roberto Aguiar Falconi ${ }^{1}$, Paola Serrano Moreta ${ }^{2}$}

1 Department of Earth Sciences and Construction, Universidad de las Fuerzas Armadas ESPE, Sangolquí, and Faculty of Engineering, Universidad Laica Eloy Alfaro de Manabí, Manabí, Ecuador

2 Universidad de las Fuerzas Armadas ESPE, Sangolquí, Ecuador

Corresponding author: Paola Serrano, pcserrano@espe.edu.ec

\section{AbSTRACT}

Seismic microzonation of the urban area of Ambato was done in 2018 in a probabilistic and a deterministic manner. This type of calculation is presented in the first part of the article. For this purpose, three geologic faults and three strong-motion equations were considered. For each geologic fault, recurrence periods are determined using two methods. It is seen that a magnitude 6.3 earthquake associated with the blind faults traversing Ambato may occur in 80 to 100 years, and one of magnitude 6.5 in the next 300 years. Geophysical and geotechnical studies of the urban area of the city of Ambato are presented. These permitted the acquisition of curves with the same period of soil vibration and equal speed of the shear wave in the first $30 \mathrm{~m}$, plus the classification of soils of the city. Later, six models of strong soil movements were considered and horizontal acceleration spectra of the soil were obtained in a mesh of points separated every $500 \mathrm{~m}$, for each soil profile. Average spectra were found for soil profiles C, D and E when making comparisons with the spectra found in the 2018 study. Based on the results of the present study and those from 2018 , new spectral forms are proposed for the urban area of the city of Ambato (called spectral envelopes) and compared to spectra reported by seismic regulations in force in Ecuador (NEC-15).

Keywords: Deterministic seismic hazard, acceleration spectra.

\section{RESUMEN}

La microzonificación sísmica del área urbana de la ciudad de Ambato fue realizada en 2018, en forma probabilística y en forma determinística; esta última forma de cálculo es la que se presenta en la primera parte del artículo. Para el efecto se consideraron tres fallas geológicas y tres ecuaciones de movimientos fuertes. Para cada una de las fallas geológicas se determinan los periodos de recurrencia empleando dos métodos: i) método del terremoto característico, y ii) método de Gutenberg y Richter

Citation: Aguiar Falconi, R., \& Serrano Moreta, P. (2021). Seismic hazard assessment of the urban area of Ambato, Ecuador, in deterministic form. Boletín Geológico, 48(2), 131-145. https://doi.org/10.32685/0120-1425/bol.geol.48.2.2021.594 
modificado, por medio de lo cual se ve que un sismo de magnitud 6,3, asociado a las fallas ciegas que atraviesan Ambato, puede registrarse dentro de 80 a 100 años, y uno de magnitud 6,5 en los próximos 300 años. Por otra parte, se presentan los estudios geofísicos y geotécnicos que se han realizado en el área urbana de la ciudad de Ambato, para obtener curvas de igual periodo de vibración del suelo, así como de igual velocidad de la onda de corte en los primeros $30 \mathrm{~m}$ y finalmente clasificar los suelos de la ciudad. Posteriormente, se consideraron seis modelos de movimientos fuertes del suelo y se obtuvieron espectros de aceleración horizontal del suelo en una malla de puntos separados cada $500 \mathrm{~m}$, para cada perfil de suelo. Se hallaron espectros promedio para perfiles de suelo C, D y E al hacer comparacioes con los espectros hallados en el estudio de 2018. Con base en los resultados hallados ahora y en los de 2018, se proponen nuevas formas espectrales para el área urbana de la ciudad de Ambato, denominadas de espectro envolvente, las cuales se comparan con los espectros que reporta la normativa sísmica vigente en Ecuador, NEC-15.

Palabras clave: Peligrosidad sísmica en forma determinística, espectros de aceleración.

\section{INTRODUCTION}

An earthquake on April 16, $2016(\mathrm{M}=7.8)$ left about six 600 dead and collapsed several dozen structures, most of them reinforced concrete of between three and seven floors in cities as important as Manta and Portoviejo, where the famous zero zone was established (Aguiar et al., 2016). Following this, municipalities in much of Ecuador did studies to determine the type of soil on which they sit, determining spectra for the design and/or repair of structures and the degree of seismic vulnerability of existing structures.

Such studies are fully justified because the zero zone of the cities mentioned and others like Pedernales and Bahía de Caráquez, which appeared like war zones with very destructive bombing. Unfortunately, many buildings built during the 1980s in Pedernales, Manta, and Portoviejo were destroyed. Other buildings of reinforced concrete with medium height (about ten floors) withstood the quake but with considerable damage in Bahía de Caráquez and Manta (Aguiar, 2017). However, their owners decided to tear them down, e.g., the Salango and Fragata buildings.

Four years have passed since the earthquake and there are empty lots in the aforementioned cities where there were buildings that were apparently earthquake resistant. Thus, the question arises: Why did these buildings have considerable damage, especially those built five years or less before the 2016 earthquake?

There are many factors leading to poor seismic behavior of structures, one being the amplification of seismic waves as an effect of soil type. For example, in the sector known as La Puntilla, in Bahía de Caráquez, modern midrise buildings su- ffered extensive damage. These sat atop a type C soil profile (a suitable soil), according to the classification of the Ecuadorian Construction Standard NEC-15. There was strong amplification of the waves because the vibration period of the ground was $\sim 0.9 \mathrm{~s}$. This is a large value, which shows that it is not adequate to classify soils with the speed of the shear wave in the first $30 \mathrm{~m}\left(\mathrm{~V}_{\mathrm{s} 30}\right)$ or based on the number of blows in the standard penetration test $\left(\mathrm{N}_{60}\right)$. It is also necessary to include the vibration period in the soil classification (Aguiar and Zambrano, 2018). Thus, the principal municipalities of Ecuador do well in conducting geophysical and geotechnical studies to classify soils from a seismic standpoint.

There are three fundamental factors for the performance of a structure during an earthquake: i) the soil (the more it is known the better); ii) the spectrum or spectra considered for design; iii) good structural performance.

The structures with poor seismic behavior during the 2016 earthquake were flexible, designed for low spectral order. Under these conditions, spectra obtained from the earthquake records were greater than those used in the design.

\section{Woriks in AMbato}

Microzonation studies were conducted in 2018 in the city of Ambato, in the center of Ecuador, which has strong commercial activity. The population in that year was $~ 180,000$ (Aguiar and Rivas, 2018). Two methods were used to define the acceleration spectra of ground movement: probabilistic, in which geological faults are grouped into seismic sources, and deterministic, wherein the hazard for specific geological faults is evaluated. 
In this article, the second method is followed. It might be asked why, if the work was already done in 2018, it was done again in 2020. The reason is that there is a new model of strong motion (Zhao et al., 2016), which the authors of the Ambato seismic microzonation study were unaware of when they did their work in the first half of 2018.

The working models in Zhao et al. (2016) are very interesting, because much of the database was obtained regarding cangahuas, which can be considered a rock like that in Ecuador. The previous model of Zhao et al. (2006) is very simple, because with a single equation one can obtain spectra and attenuation ratios of soil movement for three types of seismic sources, i.e., interphase, intraplate, and cortical.

The previous model of Zhao et al. (2006) has been used to compare the attenuation of soil movement from acceleration records of the 2016 Ecuador earthquake, so that use of the standard deviation gives reasonably good correlation.

For the deterministic calculation in the hazard study of 2018, the following strong motion equations were used: Campbell and Bozorgnia (2013), abbreviated C\&B; Abrahamson et al. (2013), ASK; Choiu and Youngs (2014), CY.

In 2018, we worked with three models of strong motion, whereas now we are working with six, the three above and the additional ones of Zhao et al. (2016), Boore and Atkinson (2008), and Akkar et al. (2014). Moreover, Aguiar and Rivas (2018) did not determine the recurrence period of the three blind faults traversing Ambato. This was determined in the present work, using the methods of the characteristic earthquake and modified Gutenberg and Richter, complementing the earlier study.

\section{Model of Zhao et AL. (2016)}

Two aspects are important in the model of Zhao et al. (2016). The first is incorporation of the soil period in the classification of seismic profiles, which was mentioned in the first section. The second has to do with the incorporation in the model of earthquakes associated with a volcano, an effect that is always important in a volcanic area. For the present study, the area is somewhat distant, so we considered minimum values recommended by the authors, but we nevertheless present four possible cases. Before this, we discuss the executive form of the Zhao et al. (2016) model, which includes two equations. One is for crustal earthquakes (source shallower than $25 \mathrm{~km}$ ) and the other for upper mantle earthquakes (source deeper than
$25 \mathrm{~km}$ ). In our case, for the seismogenic characteristics of the three faults, we treated crustal earthquakes.

\section{Crustal earthquakes}

$\log _{e}\left(y_{i, j}\right)=f_{m e r}+g_{c r} \log _{e}\left(r_{i, j}\right)$
$+g_{c r L} \log _{e}\left(x_{i, j}+200.0\right)+g_{N}\left(c_{i, j}\right)+e_{c r} x_{i, j}+e_{c r}^{v} x_{i, j}^{v}+\gamma_{c r}+\log _{e}\left(A^{c r}\right)+\xi_{i j}+\eta_{i}(1)$

\section{Upper mantle earthquakes}

$\log _{e}\left(y_{i, j}\right)=f_{\text {mum }}+g_{\text {um }} \log _{e}\left(r_{i, j}\right)$

$+g_{c c L} \log _{e}\left(x_{i, j}+200.0\right)+g_{N}\left(x_{i, j}\right)+e_{u m} x_{i, j}+e_{c r}^{v} x_{i, j}^{v}+\gamma_{c r}+\log _{e}\left(A^{u m}\right)+\xi_{i, j}+\eta_{i}$

In the equations, subscript $c r$ indicates that these are crustal earthquakes and subscript $u m$ refers to the upper mantle. With this clarification, the functions without the subscript are as follows: $f_{m}$ represents the source effect, a function of the magnitude, focal depth, and type of fault; $g$ is the rate of geometric attenuation, a function of distance and magnitude, considering in the model equations for the near field $\left(g_{N}\right)$ and long distance $\left(g_{c r L}\right) . e$ is the rate of anelastic attenuation, $e_{c r}^{v}$ is the rate of anelastic attenuation associated with the volcanic path (discussed below), and $A^{c r}$ corresponds to site functions.

The soil classification in Zhao et al. (2016) is indicated in Table 1. In the first column is the nomenclature for soil types and in the last column, their similarity to the classification of the National Earthquake Hazards Reduction Program (NEHRP) (FEMA, 2015). The second column presents a description of the soil. The third column lists classifications according to the vibration period of the soil (which is interesting). The fourth shows the value of $\mathrm{V}_{\mathrm{s} 30}$. It is important to recognize that the periods of the soils affect their classification, and that if there are soil periods $>0.6 \mathrm{~s}$, one must be concerned with problems of seismic wave amplification.

Table 1. Soil classification considered by Zhao et al. (2015) and similarity with NEHRP

\begin{tabular}{ccccc}
\hline Soil profile & Description & Period $(\mathbf{s})$ & $\boldsymbol{V}_{s 30}(\mathbf{m} / \mathbf{s})$ & $\begin{array}{c}\text { Soil profile } \\
\text { NEHRP }\end{array}$ \\
\hline SC I & Rock & $T<0.2$ & $V_{s 30}>600$ & $\mathrm{~A}+\mathrm{B}+\mathrm{C}$ \\
SC II & Hard soil & $0.2 \leq T<0.4$ & $300<V_{s 30} \leq 600$ & $\mathrm{C}$ \\
SC III & Medium soil & $0.4 \leq T<0.6$ & $200<V_{s 30} \leq 300$ & $\mathrm{D}$ \\
SC IV & Soft soil & $T \geq 0.6$ & $V_{s 30} \leq 200$ & $\mathrm{E}+\mathrm{F}$ \\
SC IV1 & & $0.6 \leq T<1.0$ & $120<V_{s 30} \leq 200$ & $\mathrm{E}$ \\
SC IV2 & & $T \geq 1.0$ & $V_{s 30} \leq 120$ & $\mathrm{~F}$ \\
\hline
\end{tabular}

Source: Zhao et al. (2015) and FEMA (2015). 
a

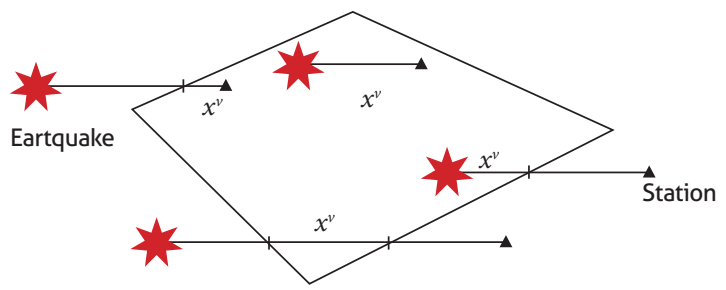

(b)

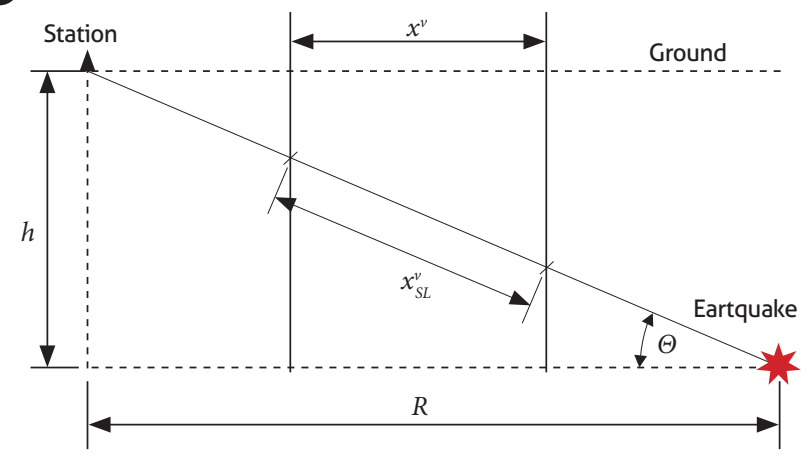

Figure 1. a) Definition of volcanic trajectory for four cases; b) volcanic distance, horizontal and inclined

Source: Zhao et al. (2016).

In some places in the city of Guayaquil, there are soil periods in the order of 3 and $4 \mathrm{~s}$. However, piles are used in building foundations in such a way that in relation to the soils of most of that city, the soils of La Puntilla of Bahía de Caráquez are suitable. Nonetheless, there were substantial amplifications of seismic waves, despite the placement of gravel piles in the reinforcement of some buildings, which stiffen the soil and decrease its period.

Thus, we have the lesson that it is inadequate to classify soil according to shear wave speed because of seismic wave amplification. Thus, it is necessary to know the vibration period of the soil, as has been done for Ambato.

The other important aspect of the Zhao et al. (2016) model is its consideration of volcanism, for which four cases are defined and shown in Figure 1: i) epicenter outside the volcanic zone (VZ) and station or point of interest within the VZ; ii) station and epicenter within the VZ; iii) epicenter in the VZ and station outside it; iv) station and epicenter outside the VZ but they cross it. In all cases, the distance $x^{v}$ is within the VZ.

\section{Blind faults in City of Ambato}

Very likely, $90 \%$ of the structural designers of the city of Ambato do not know that they are doing calculations for buildings on an active reverse fault and that an earthquake $<20 \mathrm{~km}$ deep is possible. This type of earthquake is known as impulsive and is characterized by a short duration but a dominant pulse that causes great damage to structures if they have not been properly designed.

In this regard, Ambato is built on blind geologic faults, i.e., they have no surface outcrop. Therefore, parameters such as fault type, geometry, and length have been obtained from a catalog of active faults (Eguez et al., 2003).

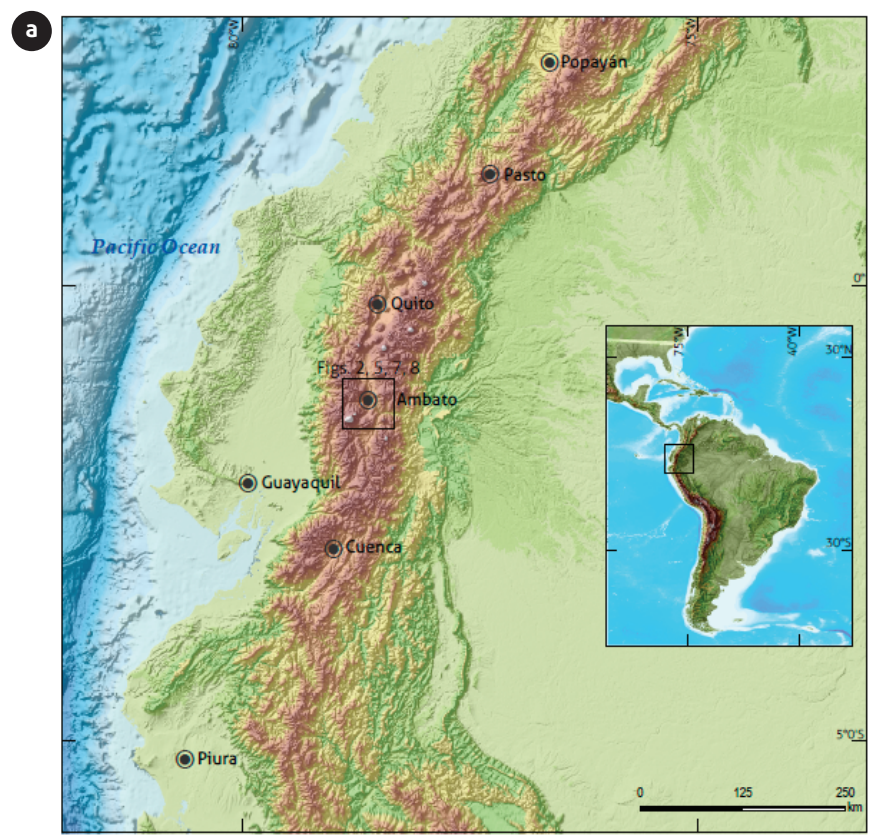

b

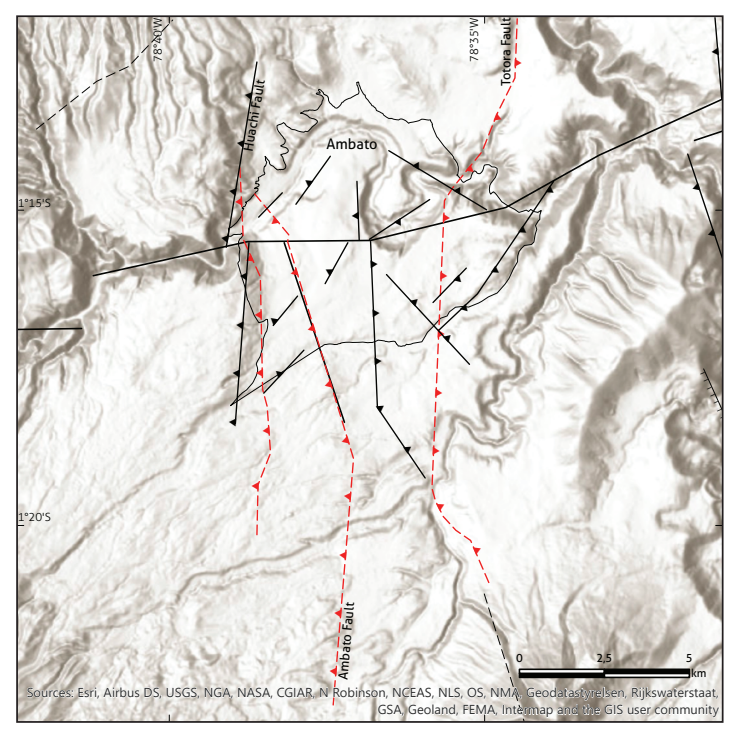

Figure 2. a) General location; b) Geologic faults selected in study of seismic hazard in urban area of Ambato

Source: Eguez et al. (2003); Chunga and Mulas (2018). 
The urban area of the city of Ambato is traversed by three faults, which are shown in Figure 2. In the upper left of the figure there is Huachi, a reverse fault with length $\sim 12.04 \mathrm{~km}$. At right is Totoras, the longest fault. It is a lateral reverse fault of length $17.65 \mathrm{~km}$. At bottom is Ambato, which is a reverse fault of 16.3 km length (Eguez et al., 2003; Chunga and Mulas, 2018).

It is important that the city of Ambato is in a valley, surrounded by mountains with steep slopes on which there is construction. Thus, there is a strong probability of landslides of large soil masses in an earthquake on one of the reverse faults. In addition, this construction mostly belongs to people with few economic resources.

Table 2 presents the faults of the study, indicating the maximum magnitude expected for each. These were found using Equations (3) and (4), proposed by Leonard (2010), and Equation (5), formulated by Wells and Coppersmith (1994) from the relationship between fault length (L), area (a), and width (W). The magnitude was found with these three proposed equations. Then, the average was obtained and rounded to the next larger value.

$$
\begin{gathered}
M_{W}=1.52 \log (L)+4.4 \\
M_{W}=1.0 \log (A)+4.0 \\
M_{W}=1.22 \log (L)+5.0
\end{gathered}
$$

Table 2. Parameters of blind faults traversing urban and rural areas of city of Ambato

\begin{tabular}{cccccccc}
\hline Fault & $\boldsymbol{\delta}$ & $\boldsymbol{\lambda}$ & $\mathbf{M}$ & $\mathbf{L}(\mathbf{k m})$ & $\mathbf{A}\left(\mathbf{k m}^{\mathbf{2}}\right)$ & $\mathbf{W}(\mathbf{k m})$ & Type \\
\hline Ambato & 45 & 90 & 6.5 & 16.3 & 97.80 & 6 & Blind reverse \\
Huachi & 45 & 90 & 6.3 & 12.04 & 72.24 & 6 & Blind reverse \\
Totoras & 45 & 90 & 6.5 & 17.65 & 105.90 & 6 & Lateral blind reverse \\
\hline
\end{tabular}

Source: Aguiar and Rivas (2018).

\section{ReCURRENCE PERIOD}

The recurrence period is different from the return period, widely used in seismic regulations for the publication of design spectra. The recurrence period is the period between earthquakes of a certain magnitude. The return period is a statistical term that relates the useful life of a structure with the probability of exceeding parameters considered in soil motion.

The two periods are complementary because it is important to know, for example, the time (in years) that it takes for a magnitude 6.5 earthquake to occur on the Totoras fault. Ob- viously, this time corresponds to a model calculation and will therefore have some uncertainty, but in this way the structural designer will have an idea that will help him or her determine the safety to ascribe to a project.

Likewise, it is important that the structural designer know the probability of exceedance of the spectrum to be used, thereby obtaining spectra for a lower or higher probability of exceedance, combined with the recurrence period.

Again by way of example, in the analysis of the 100 -year recurrence period associated with a geologic fault, it is necessary to work with an exceedance probability of $<10 \%$, because the recurrence period of a geologic fault is short and the beginning time of that period is unknown.

The first model for calculating the recurrence period is called the characteristic earthquake method, which assumes that earthquakes occur with perfect periodicity. This is a simple model that equates the accumulated seismic moment of the fault with the seismic moment released during the maximum earthquake on fault $M_{0}$ (Rivas, 2014).

$$
\begin{gathered}
T_{r}=\frac{M_{O}}{\dot{M}_{O}} \\
M_{O}=\mu \dot{u} A \\
M_{0}=10 \frac{\left(M_{W}+10.7\right) 3}{2}
\end{gathered}
$$

The as yet undefined variables are: $\mu$, stiffness modulus or shear $\left(\mu \approx 3 * 10^{9} \frac{\mathrm{kgf}}{\mathrm{m}^{2}}\right)$; the slip rate $\dot{u}$, area of the fault plane $A$; magnitude of the moment $M_{w}$.

On the other hand, the Gutenberg and Richter (1944) model, modified by Cosentino et al. (1977), assumes that during the recurrence period there may be earthquakes of lesser magnitude, for the maximum quantity of which one wishes to calculate $T_{r}$. The calculation equations are as follows.

$$
\begin{gathered}
\dot{N}_{(m)}=\dot{N}_{M_{\min }} *\left[\frac{e^{-\beta((m)}-e^{-\beta\left(M_{\max }\right)}}{e^{-\beta\left(M_{\min }\right)}-e^{-\beta\left(M_{\max }\right)}}\right] \\
\dot{N}_{M_{\min }}=\frac{\dot{M}_{0}(\bar{d}-\beta)\left(e^{-\beta M_{\min }-}-e^{\left.-\beta M_{\max }\right)}\right.}{\beta\left[e^{-\beta M_{\max }} M_{0}\left(M_{\max }\right)-e^{-\beta M_{\min }} M_{0}\left(M_{\min }\right)\right]} \\
M_{0}\left(M_{\min }\right) e^{\left(\bar{c}+\bar{d} M_{\min }\right)} \quad M_{0}\left(M_{\max }\right) e^{\left(\bar{c}+\bar{d} M_{\max }\right)} \\
\bar{c}=16.05 * \ln (10) \quad \bar{d}=1.5 * \ln (10)
\end{gathered}
$$

Here, $\dot{N}_{(m)}$ is the accumulated rate of earthquakes with magnitude $\geq m$. It is the accumulated rate of earthquakes of 
magnitude $\geq M_{\text {min }}$ (the minimun magnitude). $M_{\max }$ is the maximum magnitude considered. $\beta$ is a parameter of fault seismicity. $M_{0}\left(M_{\min }\right)$ is the minimum seismic moment and $M_{0}\left(M_{\max }\right)$ the maximum seismic moment.

Once the considered magnitude has been obtained, we determine $\dot{N}_{(m)}$ and the non-annual accumulated rate of earthquakes $\hat{N}_{(m)}$, which is obtained by subtracting the accumulated annual rate of two consecutive quantities to ultimately determine the recurrence period, which is the inverse of the non-accumulated annual rate.

It is important to note that the accumulated rate of seismic moment is assumed to be released by earthquakes of different magnitudes and is between $M_{\min }$ and $M_{\max }$, the latter determined by the size of the fault plane.

Considering the equation of Gutenberg and Richter (1944), it follows that

$$
\log N=a-b M
$$

Here, $N$ is the number of earthquakes of magnitude $\geq M$ and $a$ and $b$ are seismicity parameters of the fault. However, the Ambato, Huachi and Totoras faults are in source zone 6 of the model of Beauval et al. (2018), and for that zone (known as the Pallatanga fault) these parameters are: $a=2.8012, b=0.73$, which were adopted for the three blind faults in the city of Ambato. Equation (13) can then be written as follows.

$$
\begin{gathered}
\ln N=\alpha-\beta m \\
\alpha=a \ln 10 \quad \beta=b \ln 10
\end{gathered}
$$

In Equation (15) we have the parameter $\beta$, which appears in Equations (9) and (10). Finally are defined all calculation equations to determine the recurrence period in the two models. It only remains to mention that we took $\dot{u}=3.5 \mathrm{~mm} / \mathrm{yr}$, because Alvarado et al. (2014) stated that for a fault system, the rate of motion is between 3.0 and $4.0 \mathrm{~mm} / \mathrm{yr}$.

Figure 3 presents graphically the recurrence period results for each blind fault crossing Ambato. Figure 3a shows results of the characteristic earthquake method and Figure $3 \mathrm{~b}$ those from Gutenberg and Richter.

Based on the results, we can say that for a magnitude of maximum moment $=6.5$, associated with the blind faults of Ambato and Totoras, the period is $\sim 600$ years. For an earth- quake of magnitude of maximum moment $=6.3$, related to the Huachi fault, that period is $\sim 400$ years.

The city of Ambato was founded on August 24, 1534, and was destroyed by an earthquake on June 20, 1698, which was short-lived. We assume that this was associated with one of the blind faults in the city. Therefore, a second foundation of the city occurred in 1698, and since that time there have been no earthquakes that could be associated with the blind faults of Ambato.

The Riobamba earthquake of February 4, 1797 completely destroyed the ancient city of Riobamba and caused very severe damage in Ambato, but it was not related to the blind faults of the city. Something similar can be said of the earthquake on August 5, 1949, which also destroyed Ambato but whose epicenter was in Pelileo, distant from the city.

The faults portrayed in Figure 2 are in source zone 6, known as the Pallatanga fault from the model of Beauval et al. (2018). We cite this reference because we used the seismicity parameters $a=2.8012$ and $b=0.73$ from the classical model of Gutenberg and Richter $\log N=a-b M$, whose values were found for source zone 6.

Table 3 lists the calculated recurrence periods associated with Ambato fault, and Table 4 the values for Huachi and Totoras faults.

The characteristic earthquake method assumes that earthquakes occur with perfect periodicity, obtaining a return period

Table 3. Recurrence period from GR model modified for Ambato fault

\begin{tabular}{cccc}
\hline $\boldsymbol{m}$ & $\begin{array}{c}\text { Accumulated annual rate } \\
\dot{\boldsymbol{N}}_{(\boldsymbol{m})}\end{array}$ & $\begin{array}{c}\text { Non-accumulated } \\
\text { annual rate } \\
\hat{\boldsymbol{N}}_{(\boldsymbol{m})}\end{array}$ & $\begin{array}{c}\text { Recurrence period } \\
\text { (years) }\end{array}$ \\
\hline 4.5 & 0.0490 & 0.0289 & 34.65 \\
5.0 & 0.0201 & 0.0125 & 80.31 \\
5.5 & 0.0077 & 0.0054 & 186.11 \\
6.0 & 0.0023 & 0.0023 & 431.28 \\
6.5 & 0.0000 & 0.0001 & 676.45 \\
\hline
\end{tabular}

Table 4. Recurrence period from GR model modified for Huachi and Totoras faults

\begin{tabular}{cccccccc}
\hline \multicolumn{4}{c}{ Huachi } & \multicolumn{6}{c}{ Totoras } \\
\hline $\boldsymbol{m}$ & $\dot{\boldsymbol{N}}_{(\boldsymbol{m})}$ & $\hat{\boldsymbol{N}}_{(\boldsymbol{m})}$ & $\begin{array}{c}\boldsymbol{T}_{\boldsymbol{r}} \\
\text { (years) }\end{array}$ & $\boldsymbol{m}$ & $\dot{\boldsymbol{N}}_{(\boldsymbol{m})}$ & $\hat{\boldsymbol{N}}_{(\boldsymbol{m})}$ & $\begin{array}{c}\boldsymbol{T}_{\boldsymbol{r}} \\
\text { (years) }\end{array}$ \\
\hline 4.5 & 0.0510 & 0.0305 & 32.82 & 4.5 & 0.0530 & 0.0312 & 32.04 \\
5.0 & 0.0205 & 0.0131 & 76.05 & 5.0 & 0.0218 & 0.0135 & 74.25 \\
5.5 & 0.0074 & 0.0057 & 176.24 & 5.5 & 0.0083 & 0.0058 & 172.06 \\
6.0 & 0.0017 & 0.0017 & 276.43 & 6.0 & 0.0025 & 0.0025 & 398.73 \\
6.3 & 0.0000 & 0.0000 & 336.54 & 6.5 & 0.0000 & 0.0000 & 625.40 \\
\hline
\end{tabular}




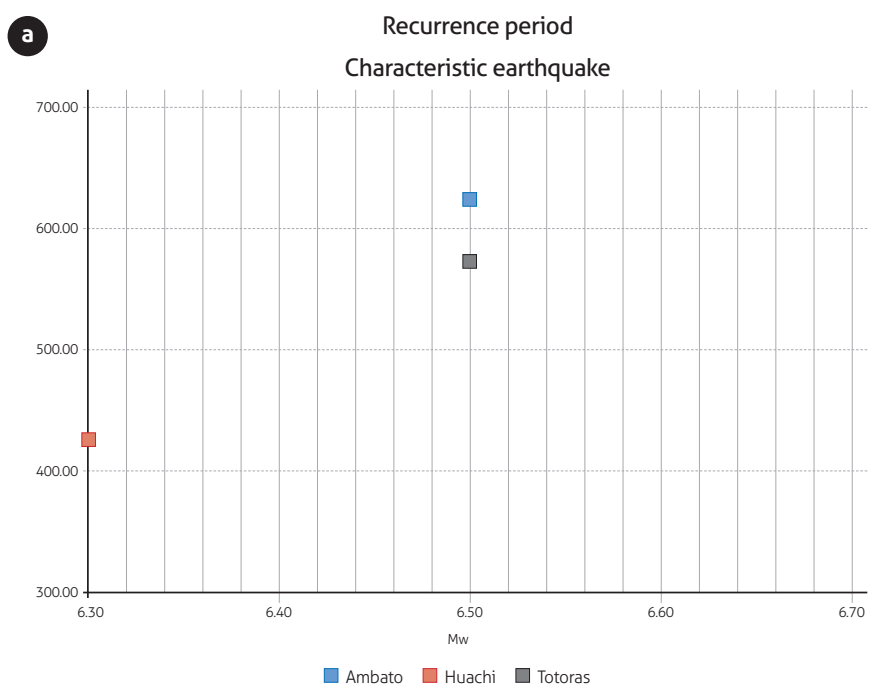

Figure 3. Recurrence periods for blind faults crossing Ambato.

a) characteristic earthquake method; b) modified Gutenberg and Richter method.

for a specific moment magnitude, whereas the Gutenberg and Richter model treats the probability that a fault produces earthquakes of different magnitudes with varying recurrence periods.

Given the above, 1698 can be considered the start year to determine roughly when the next earthquake associated with the Huachi, Ambato and Totoras faults will occur. Based on our results, an earthquake of magnitude 6.3 , associated with Huachi, is expected between 80 and 100 years hence, and a magnitude 6.5 in $\sim 80-700$ years.

A major problem is that a sizeable part of the city would not be able to withstand a magnitude 6.3 quake with focal depth $\sim 10 \mathrm{~km}$. This is asserted based on the Study of Seismic Vulnerability for the city of Ambato, in which a seismic analysis of $\sim 450$ structures was carried out (Aguiar, 2018).

\section{Geophysical AND GeOteChNICAL StUdies}

At nine sites in the urban area of the city of Ambato (indicated in Figure 4), data of the active source were obtained from an impact that generated waves recorded by geophones (active source) and environmental vibration (passive source, MASW). We applied the combined method to these two databases and determined the shear wave speed $V_{s}$, reaching at least $50 \mathrm{~m}$ depth, to obtain $V_{s}$ in the first 30 meters (designated $V_{s 30}$ ) as one of the parameters used for the soil classification (Aguiar and Rivas, 2018).

The period of soil vibration was obtained for the above locations using other measurement equipment (SARA), using environmental vibration and the Nakamura method.

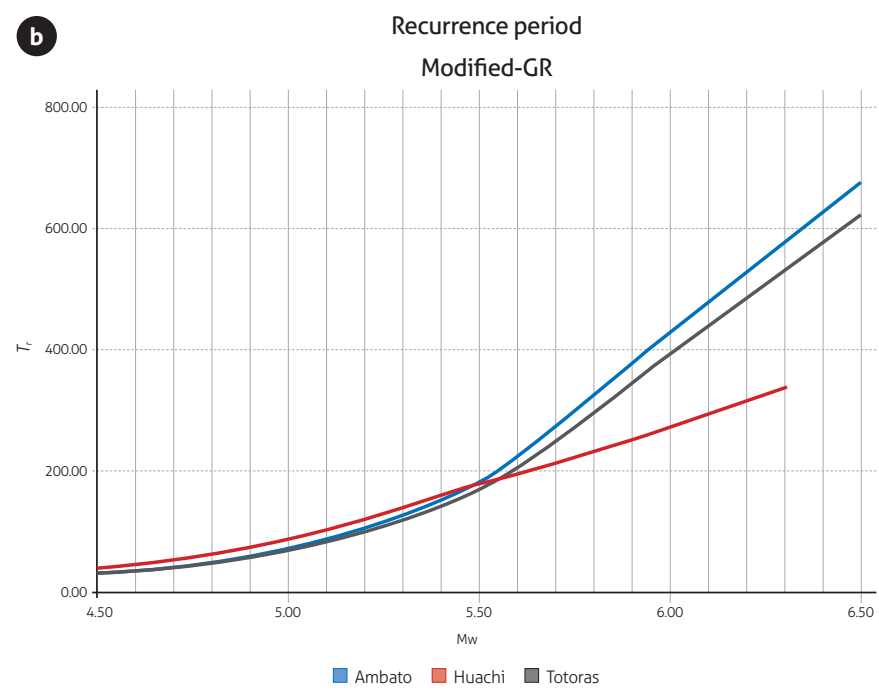

The periods of vibration found determined curves of the same period (Figure 5a), which varied between 0.11 and $0.45 \mathrm{~s}$. Thus, from the point of view of seismic wave amplification, soils of the city of Ambato can be classified as favorable.

Furthermore, using the values of $V_{s 30}$, we constructed the curve of equal shear wave speed values in the first $30 \mathrm{~m}$ (Figure $5 b)$, which is generally between 300 to $450 \mathrm{~m} / \mathrm{s}$. These values correspond to favorable soil from a seismic perspective. There are very specific sites corresponding to creek fills that had $V_{s 30}$ on the order of $120 \mathrm{~m} / \mathrm{s}$.

To classify soils seismically requires determination of the number of blows $\left(N_{60}\right)$ obtained with the standard penetration test (SPT), for which we conducted geotechnical studies at the same locations as the geophysical studies (Figure 6; also shown in the photos of Figure 4).

Drillings to $30-\mathrm{m}$ depth did not reach the water table, which helped further validate that the soils of Ambato are resistant. In addition to finding the value of $N_{60}$, during the test we obtained unaltered soil samples at some sites, and at other sites altered. With these, we performed triaxial laboratory tests to determine cohesion and the friction angle of the soil (Aguiar and Rivas, 2018).

The soils of Ambato were classified following the NEC-15 classification method and using the following information: $V_{s 30}$, period of vibration of the soil $T_{s}, N_{60}$, values of cohesion $c$, angle of internal friction $\Phi$, and ground shear. The results are presented in Figure 7. 

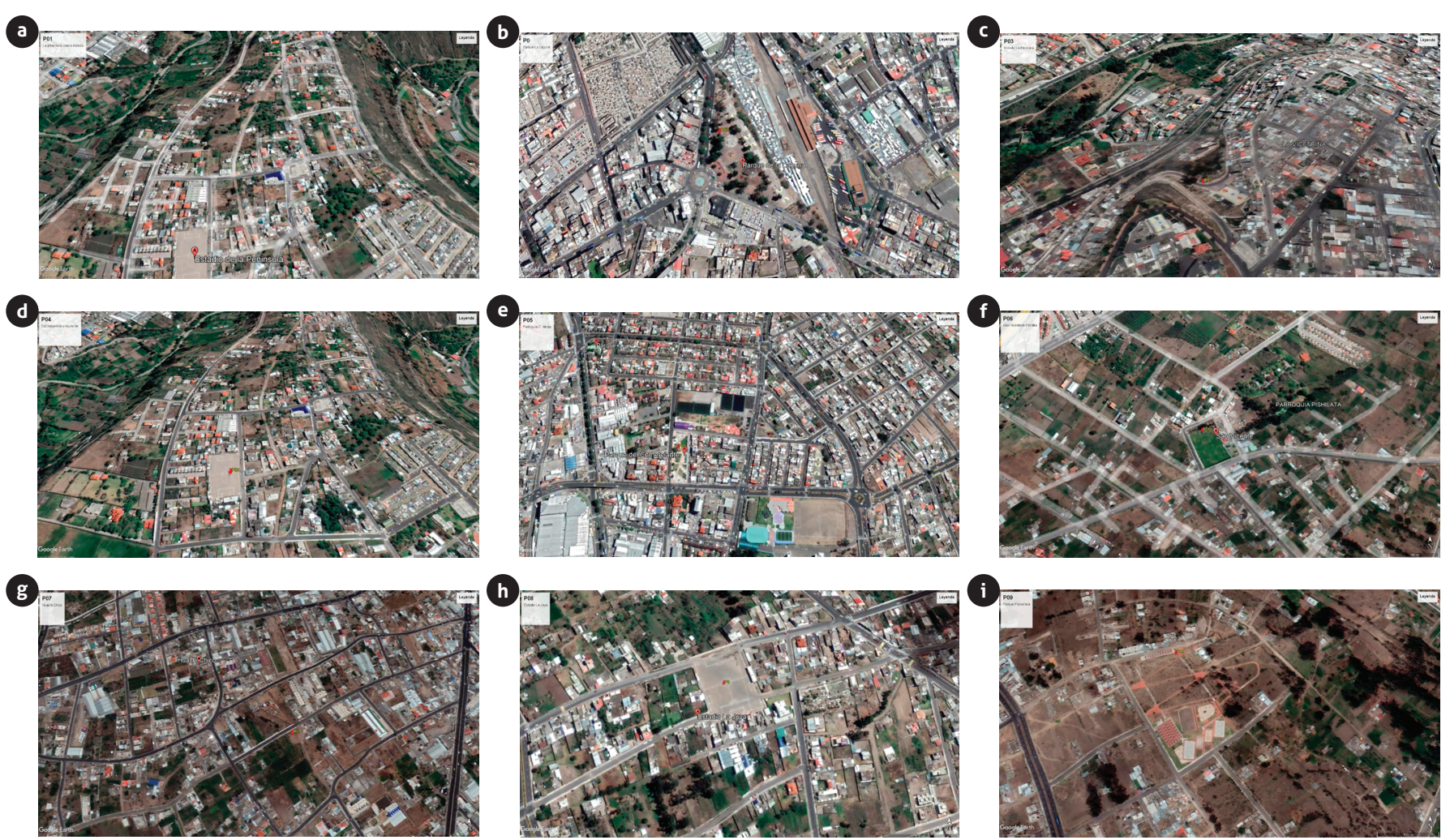

Figure 4. Sites of geophysical studies

a) San Luis stadium; b) La Laguna park; c) La Floreana stadium; d) La Península neighborhood league; e) Celiano Monje park; f) San Vicente de Pishilata neighborhood league; g) green area of Huachi Chico; h) La Joya stadium; i) Pasochoa park. Source: Aguiar and Rivas (2018).
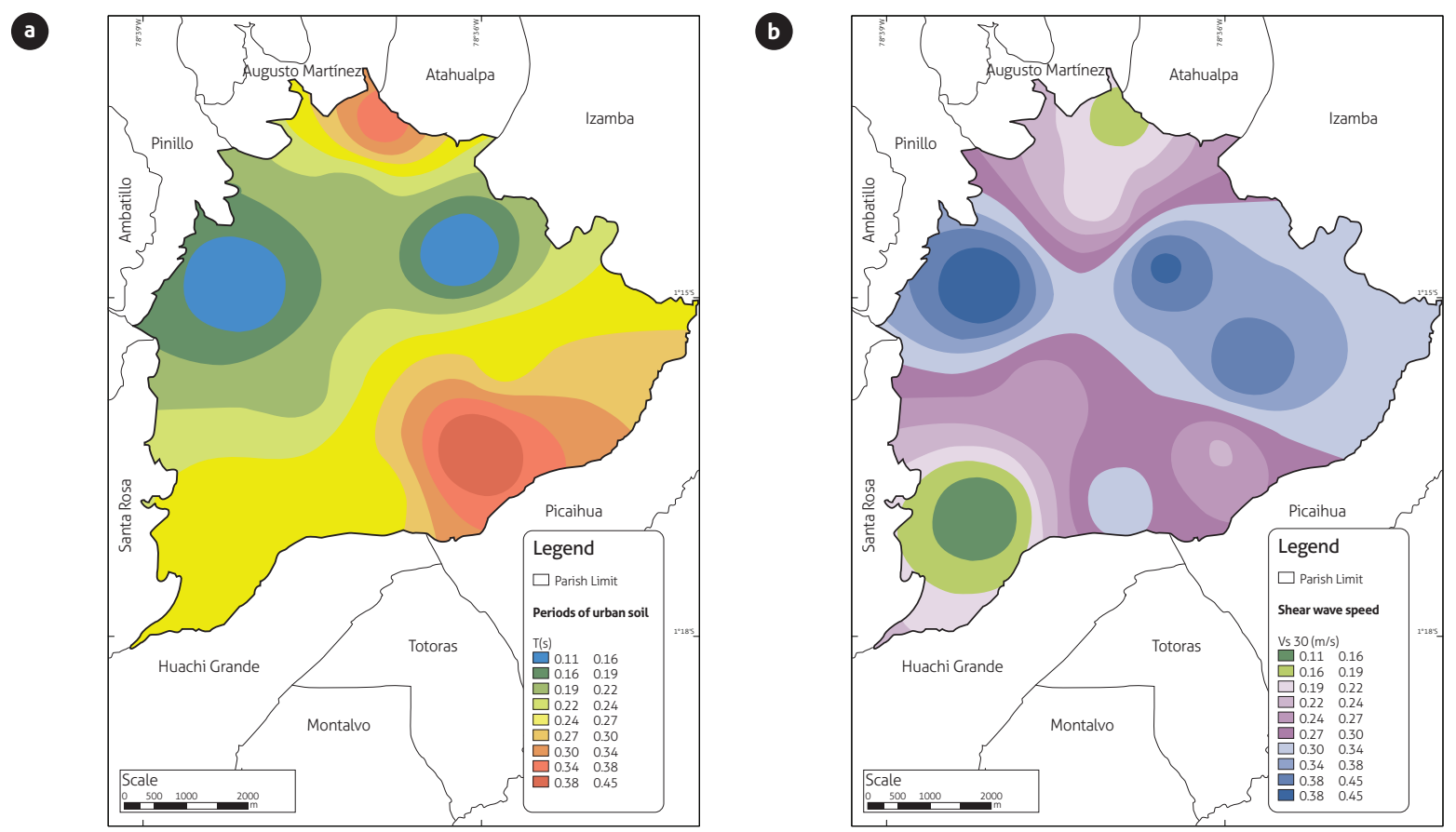

Figure 5. Studies of seismic hazard of urban area of city of Ambato: a) soil vibration period; b) shear wave speed in the first $30 \mathrm{~m}$ Source: Aguiar and Rivas (2018). 


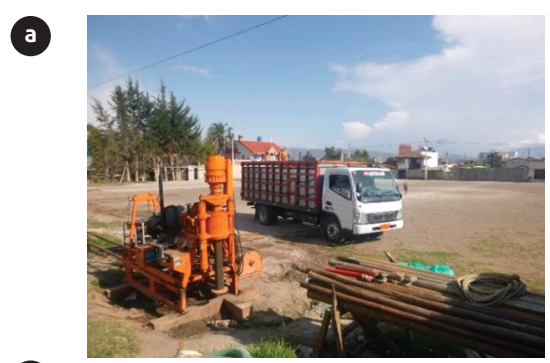

(

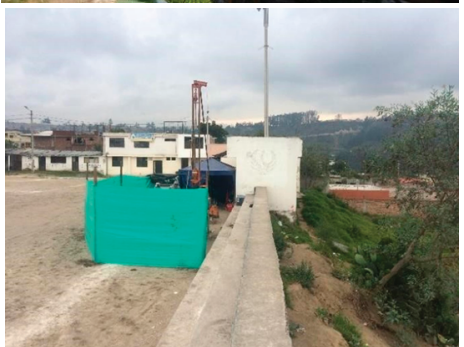

g

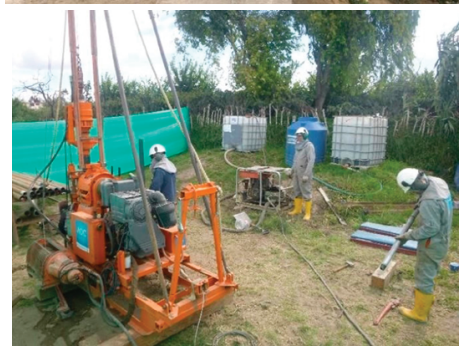

(b)

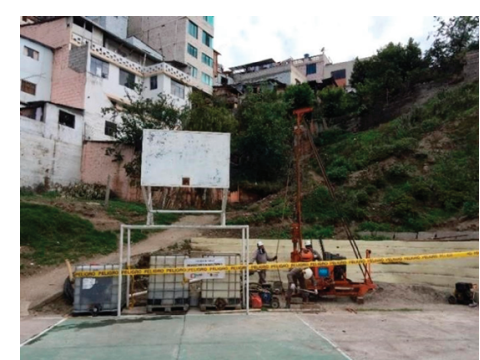

e

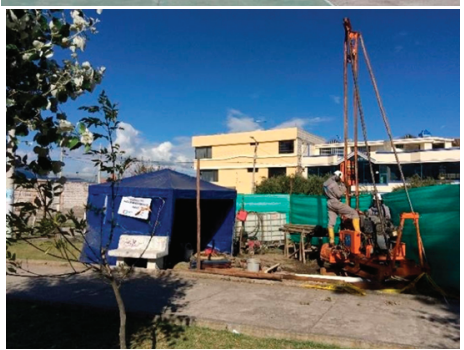

(h)

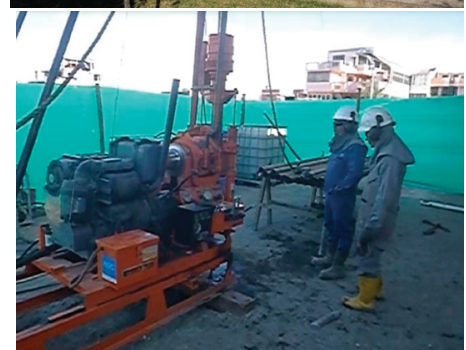

c

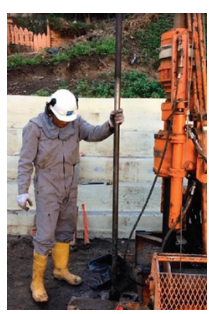

(

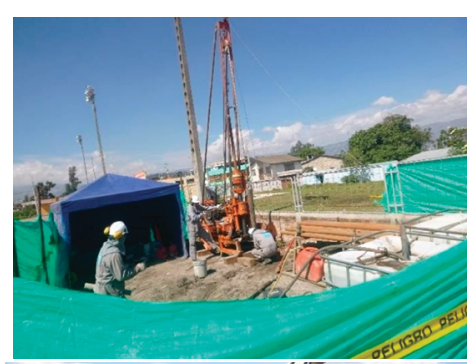

(i)

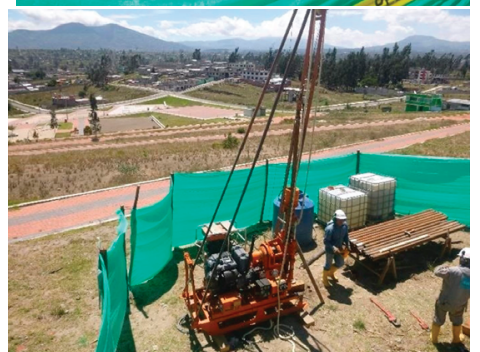

Figure 6. Sites of standard penetration tests (SPT), at the same locations as the geophysical studies Source: Aguiar and Rivas (2018).

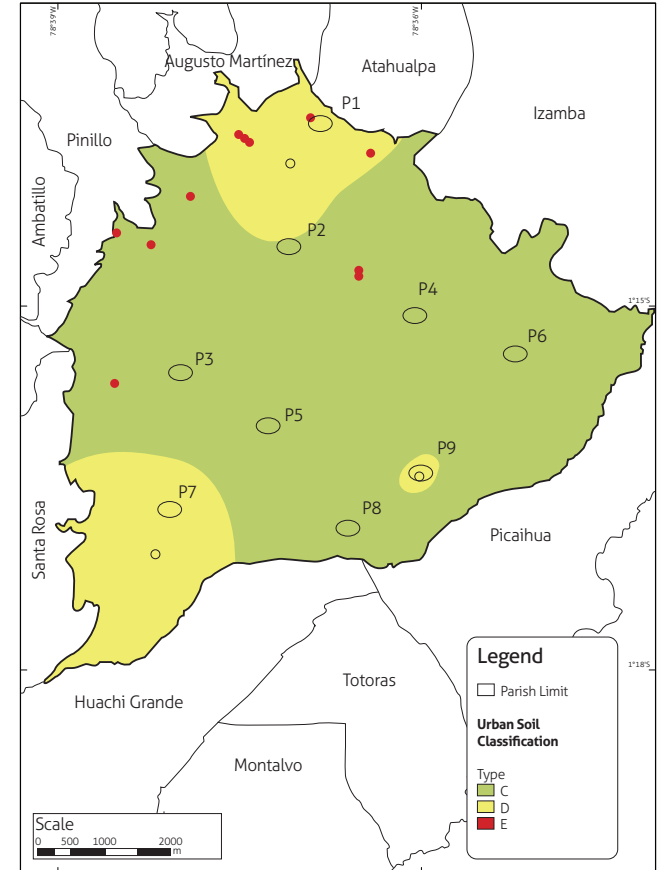

Figure 7. Classification of soils in city of Ambato from standpoint of seismic hazard

Source: Aguiar and Rivas (2018).
Figure 7 reveals that most of the soils of Ambato are of type $C$ and D. As indicated, there are several parameters involved in the soil classification, but $V_{\mathrm{s} 30}$ is the most used in the models of strong motion, For this reason, the range of $V_{s 30}$ according to soil type is indicated very briefly below, following the NEC-15 standard (Table 5).

Table 5. Soil classification according to NEC-15 and NEHRP (FEMA, 2015)

\begin{tabular}{cc}
\hline Soil profile & $\boldsymbol{V}_{s 30}$ \\
\hline A & $V_{s 30}>1500 \mathrm{~m} / \mathrm{s}$ \\
B & $760 \mathrm{~m} / \mathrm{s}<V_{s 30} \leq 1500 \mathrm{~m} / \mathrm{s}$ \\
C & $360 \mathrm{~m} / \mathrm{s}<V_{s 30} \leq 760 \mathrm{~m} / \mathrm{s}$ \\
D & $180 \mathrm{~m} / \mathrm{s}<V_{s 30} \leq 360 \mathrm{~m} / \mathrm{s}$ \\
E & $V_{s 30} \leq 180 \mathrm{~m} / \mathrm{s}$ \\
\hline
\end{tabular}

Source: NEC-15.

\section{Spectra of HoRIZONTAL ACCELERATION}

To calculate the acceleration spectra with respect to the horizontal component of soil movement using the deterministic 
method, the urban area of the city of Ambato was divided into three grids with points separated by $500 \mathrm{~m}$ in both horizontal directions. Figure 8 a shows the grid in a general way and Figure $8 \mathrm{~b}$ the grid for soil profiles $\mathrm{C}, \mathrm{D}$ and $\mathrm{E}$.

The horizontal acceleration spectra were calculated for each soil profile, considering an earthquake of maximum magnitude on each of the blind faults (Huachi, Ambato and Totoras). The focus of this earthquake was located at the center of gravity of the fault. For each equation of strong motion, we found control spectra at all grid points, ultimately obtaining an average. These spectra are presented below and were determined using an EXCEL program developed for the purpose.

For a soil profile $C$, the calculation was done using $V_{s 30}=340 \mathrm{~m} / \mathrm{s}$. For a soil profile D, $V_{s 30}=300 \mathrm{~m} / \mathrm{s}$, and for a soil profile E, $V_{s 30}=180 \mathrm{~m} / \mathrm{s}$.
Figure 9a shows average spectra for an earthquake of maximum magnitude $(M=6.3)$ on the Huachi fault, for which the spectra were determined at each grid point and the average value was established. This was done for each strong motion equation. The model of Zhao et al. (2016) produced the largest spectral ordinates, in an area with short periods.

The spectra in Figure $9 \mathrm{~b}$ correspond to the average of values from each of the six models, which is identified as "Spectra 2020". The average spectra from three equations of strong motion used in the 2018 study are labeled "Spectra 2018".

Figure $9 \mathrm{c}$ and $\mathrm{d}$ is analogous, but for a maximum-magnitude earthquake on the Ambato fault $(M=6.5)$. Finally, Figure $9 \mathrm{e}$ and $\mathrm{f}$ shows results for a maximum-magnitude earthquake $(\mathrm{M}=6.5)$ on the Totoras fault. It is interesting to compare the spectra of Figures $9 \mathrm{~b}, \mathrm{~d}$ and $\mathrm{f}$, which is done in the next section.
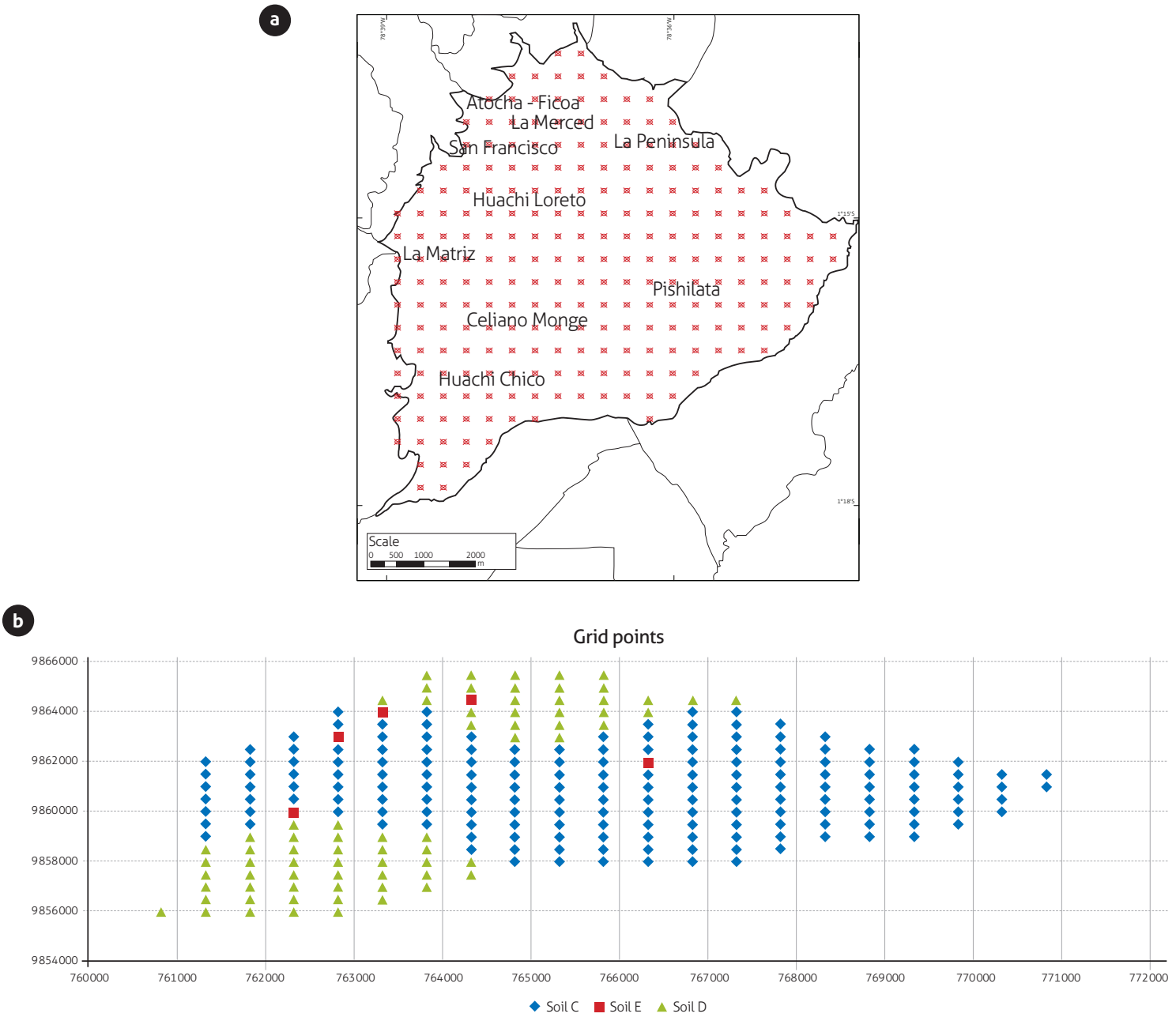

Figure 8. a) Grid points in urban area of Ambato; b) profiles of soils C, D and E 
As with the type $\mathrm{C}$ soil profile, we proceeded with the type $\mathrm{D}$ and $\mathrm{E}$ soils in the city of Ambato, obtaining the average spectra in Figures 10 and 11 (considering an earthquake of maximum magnitude on each fault).

In general, Spectra 2020 has greater ordinates than Spectra 2018, but not in all periods. Indeed, for an earthquake on the Totoras fault $(M=6.5)$, the spectral ordinates of Spectra 2018 are slightly greater. However, for short periods, the spectral ordinates of Spectra 2020 are slightly greater than those of Spectra 2018, but for the remaining periods they are very similar.
。

a Average value of model spectra CY13, CB13, ASK13, ZHAO16, BA08, A\&B14 for Ambato (2020)

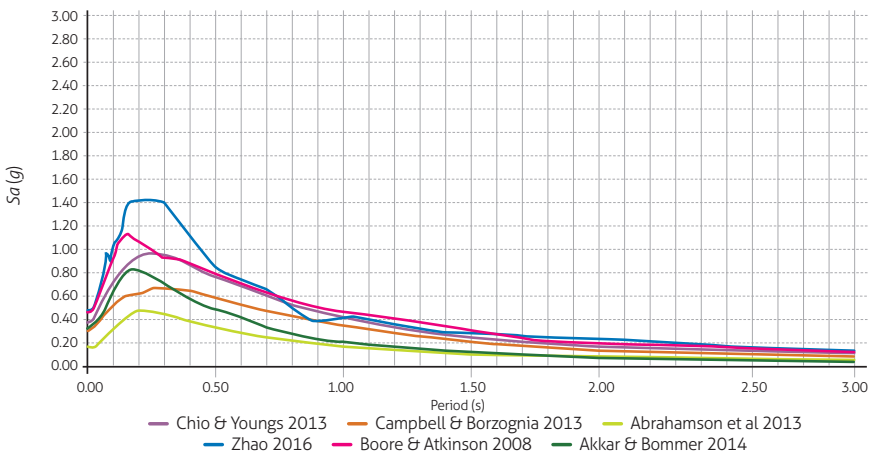

c Average value of model spectra CY13, CB13, ASK13, ZHAO16, BA08, A\&B14 for Ambato (2020)

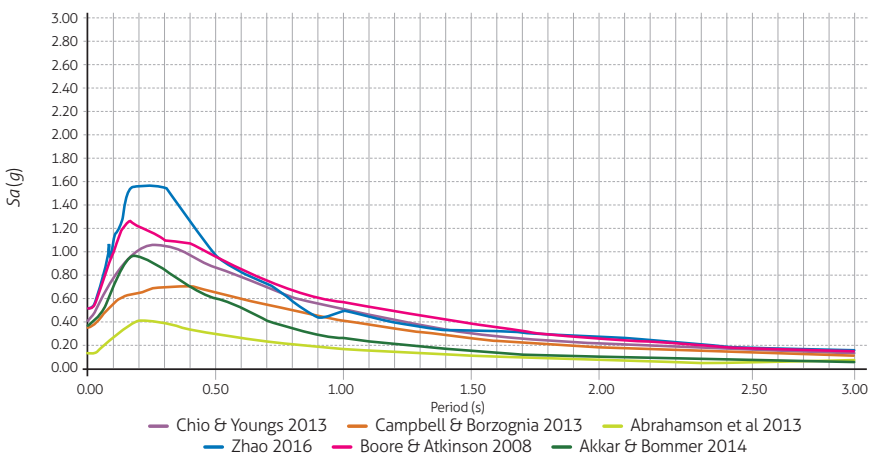

e Average value of model spectra CY13, CB13, ASK13, ZHAO16, BA08, A\&B14 for Ambato (2020)

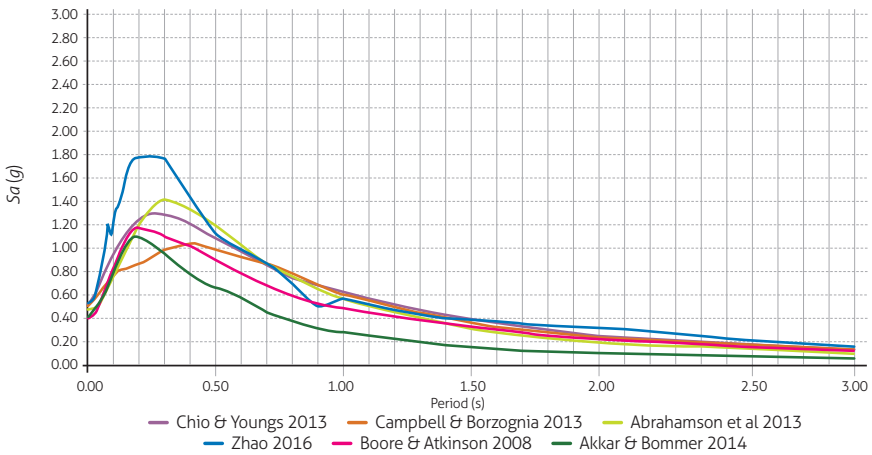

(อ

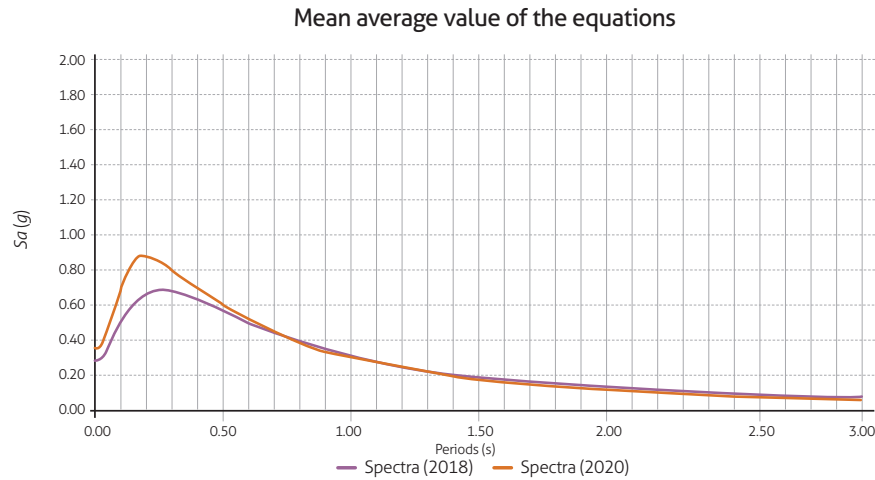

○

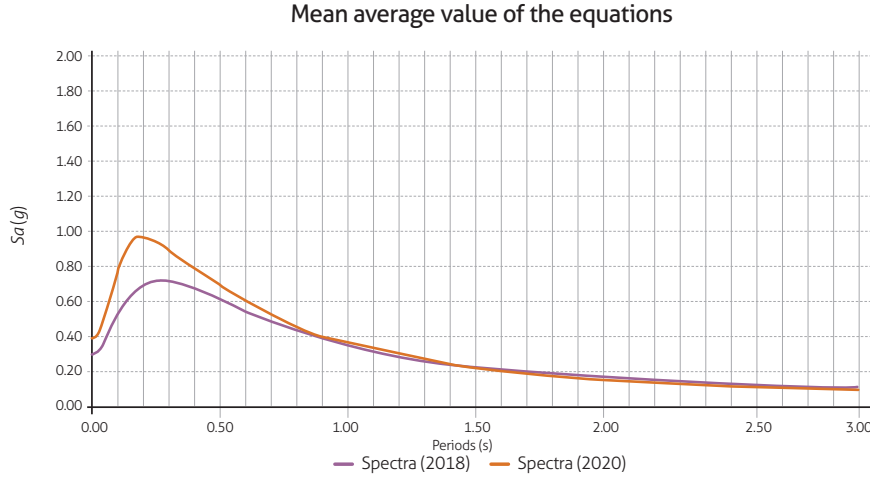

๑

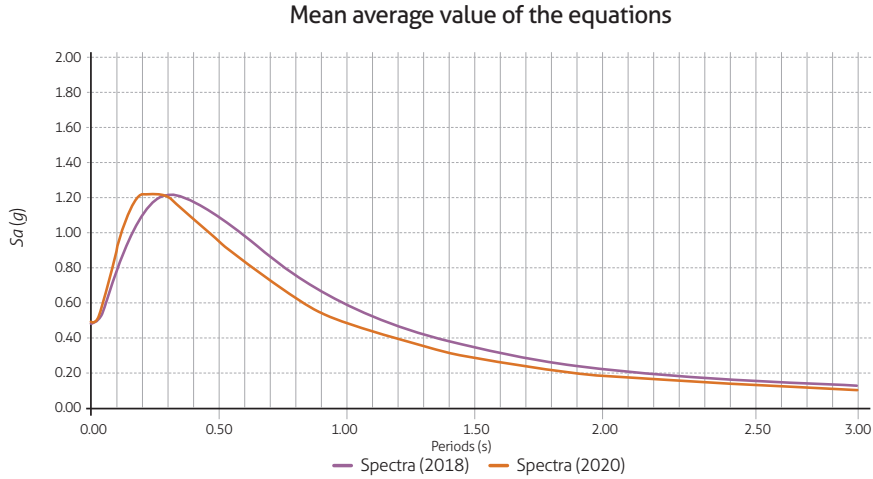

Figure 9. Spectra in a C soil profile

a) Earthquake on Huachi fault from all models; b) average spectra from studies of 2018 and 2020; c) earthquake on Ambato fault from all models; d) average spectra from studies of 2018 and 2020; e) earthquake on Totoras fault from all models; f) average spectra from studies of 2018 and 2020. 
a

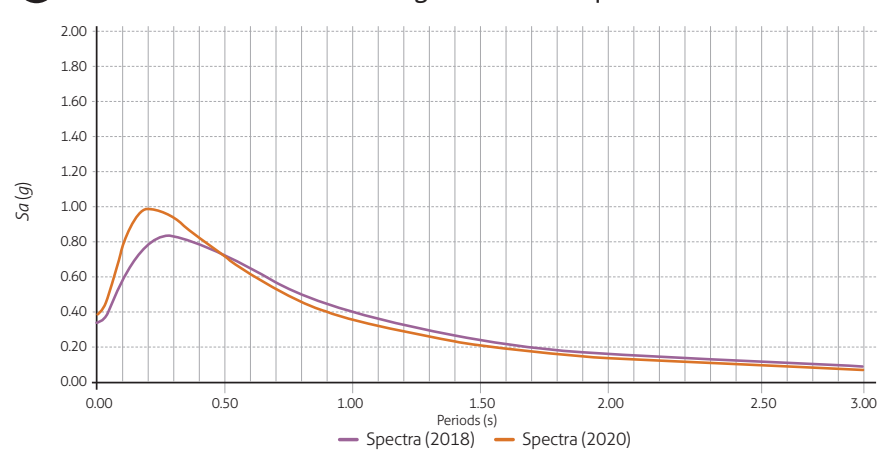

b

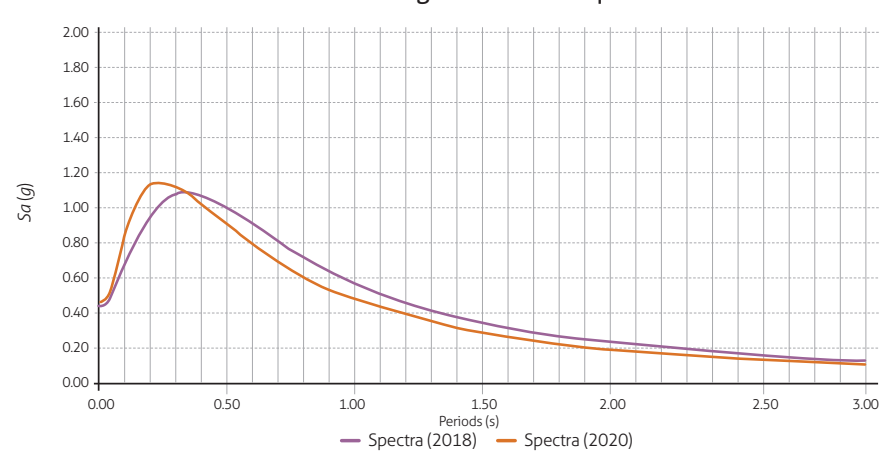

c

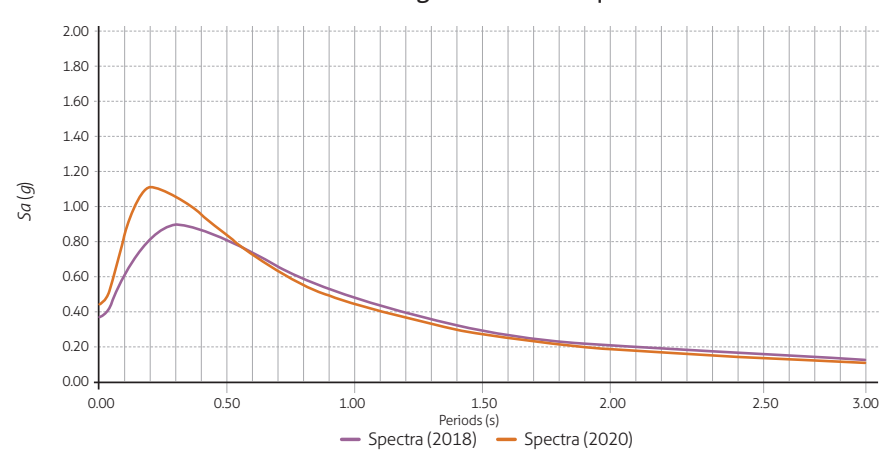

Figure 10. Average spectra in a soil profile D, found using the six equations of strong motion in present study and three equations from study of 2018

a) Earthquake on Huachi fault; b) earthquake on Ambato fault; c) earthquake on Totoras fault.

\section{Spectral envelopes}

With the values of Spectra 2020 and Spectra 2018 we determined a spectral envelope from averages of seismic hazard studies in 2018 and 2020 for soil type C shown in Figure 9b, d and f. For soil type D we considered the spectra of Figure 10, and for type E those of Figure 11.

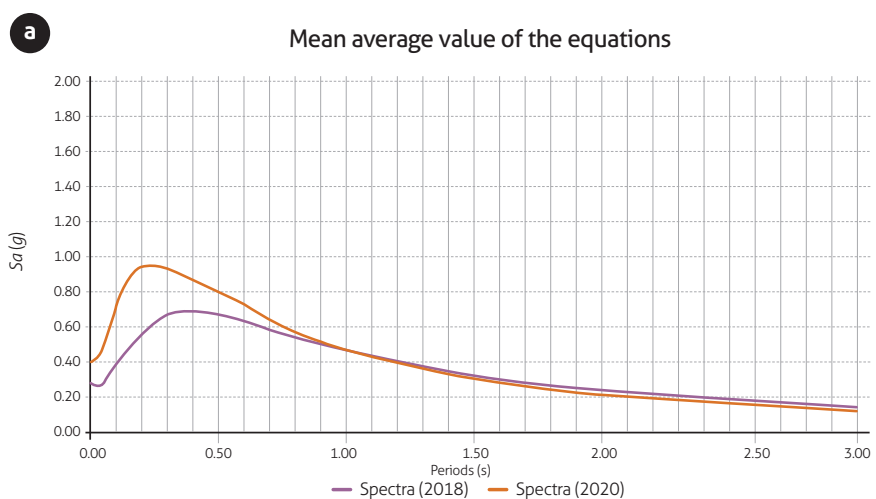

(b)

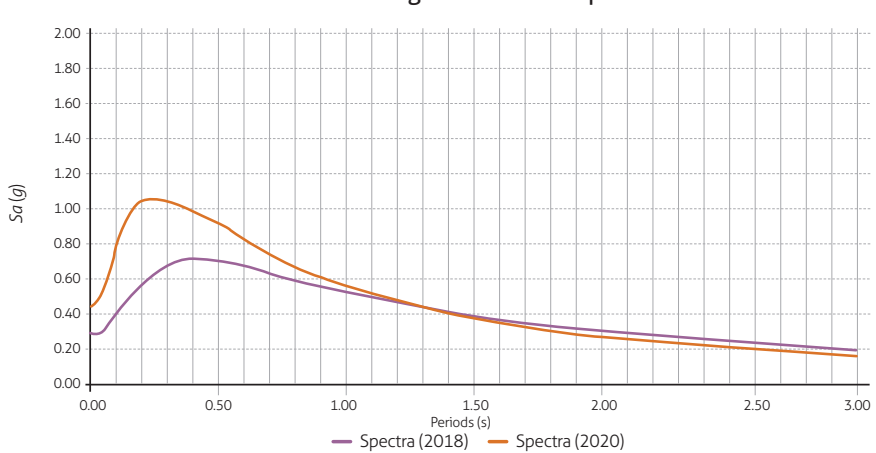

c

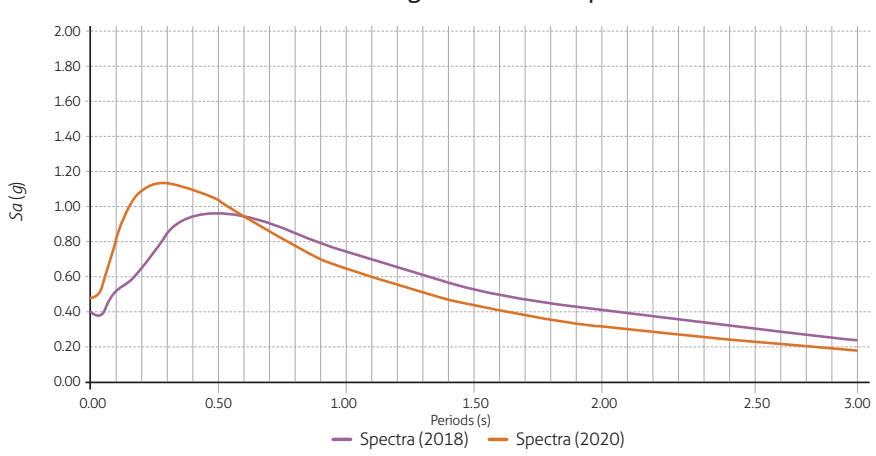

Figure 11. Average spectra in soil profile E, found using the six equations of strong motion in present study and three equations of study of 2018

a) Earthquake on Huachi fault; b) earthquake on Ambato fault; c) earthquake on Totoras fault.

For the spectra associated with type D soil from each strong motion model, Figure 12 presents these values and the spectral envelope.

There are clearly periods in which the spectral ordinate found by a model is greater than the spectral envelope, but the values are $<10 \%$ of the probability of exceedance. 


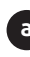

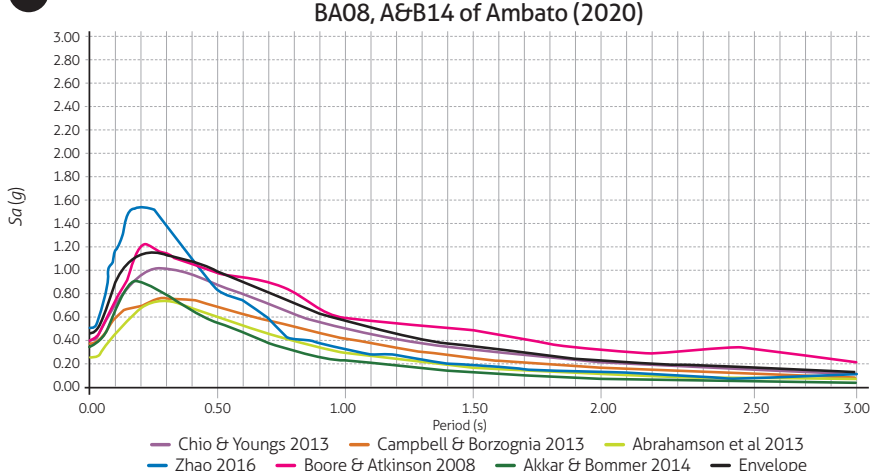

b Mean value and spectral envelope for model CY13, CB13, ASK13, ZHAO16,

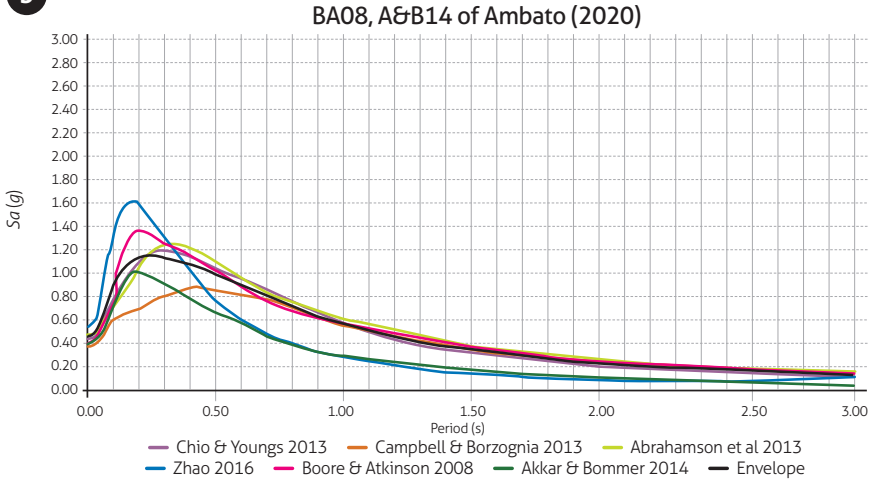

c Mean value and spectral envelope for model CY13, CB13, ASK13, ZHAO16,

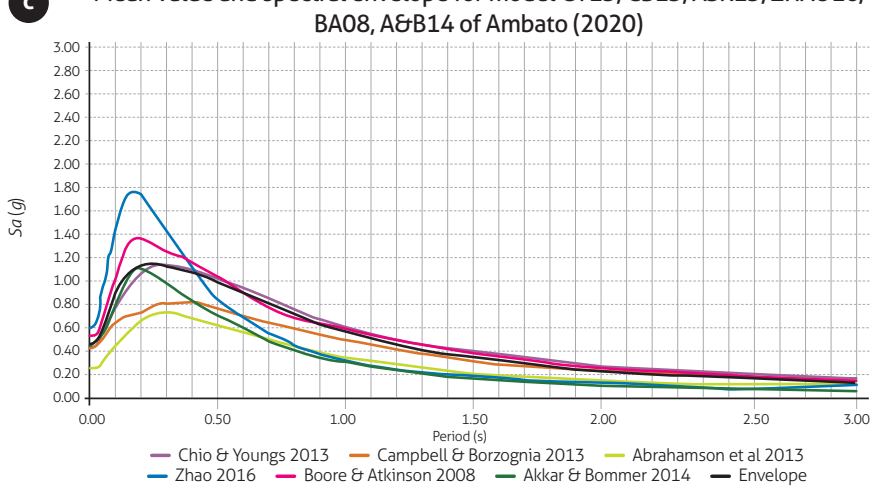

Figure 12. Spectra from each of six models in the study and spectral envelope derived from average values of seismic hazard studies in 2018 and 2020

a) Earthquake on Huachi fault $(M=6.3)$; b) earthquake on Ambato fault ( $M=$ $6.5)$; c) earthquake on Totoras fault $(\mathrm{M}=6.5)$.

We then compared spectral envelopes with reports in the Ecuadoran Standard of Construction (NEC-15) for three soil profiles (Figure 13a) in a C seismic soil profile. There was a good approximation between the two.

Figure 13b compares the spectra for a soil profile $\mathrm{D}$, which suggests a reduction in spectral shape for long periods. Finally, Figure $13 \mathrm{c}$ shows the spectra for a soil profile E, which differ
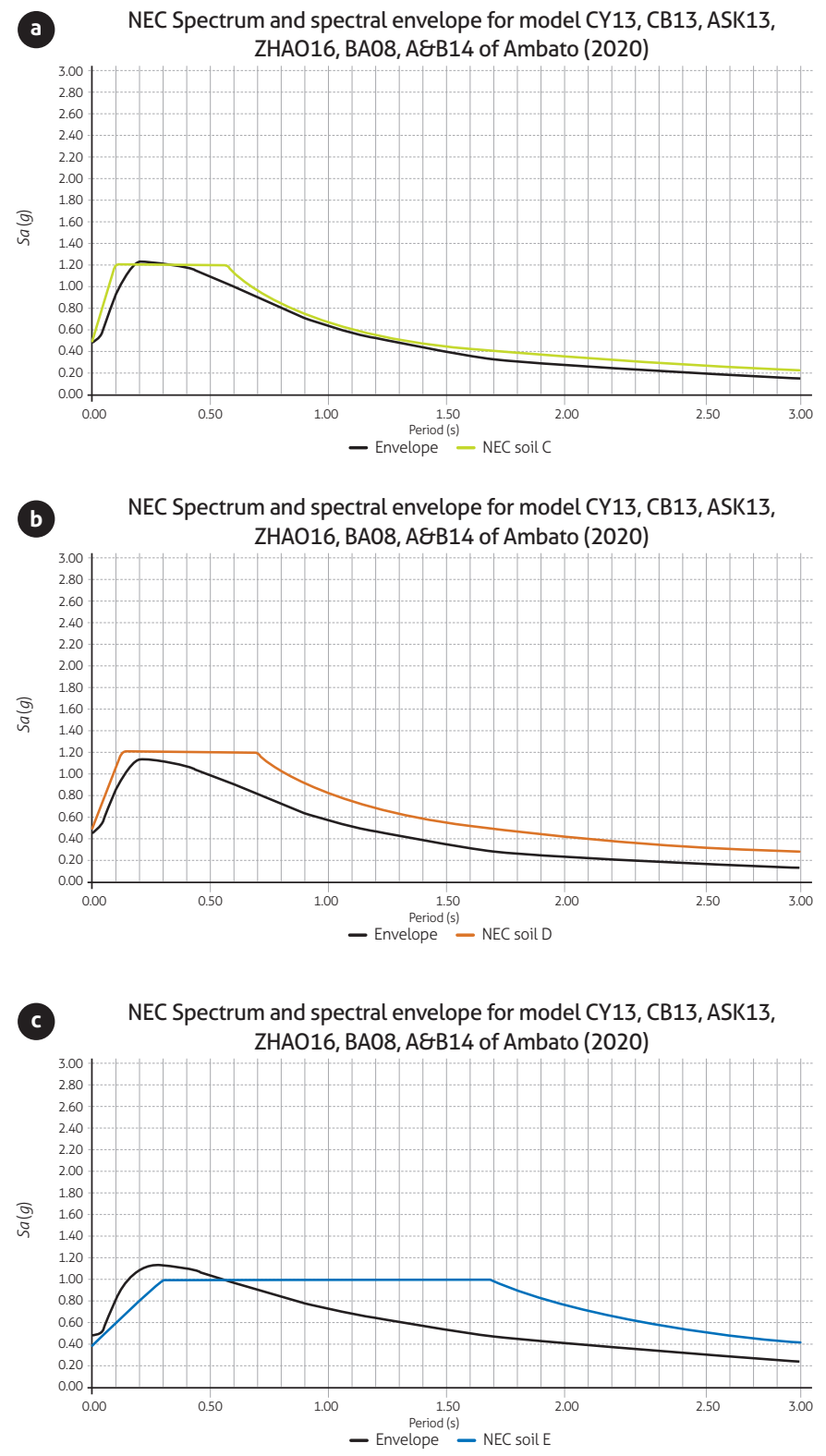

Figure 13. Comparison of spectral envelopes with those reported in NEC-15 a) Soil type C; b) soil type D; c) soil type E.

the most with respect to the spectrum of NEC-15. Here, for the constant acceleration platform, the spectral ordinates are $\sim 1.2 \mathrm{~g}$.

The results of our study are very valuable and make an important contribution to comparing spectra obtained from the probabilistic method, in order to finally determine the shape of the spectra for the city of Ambato. 


\section{Comments And Conclusions}

After the 2016 earthquake of Pedernales ( $M=7.8)$, which left much destruction and death in the provinces of the northern coast of Ecuador, some municipalities decided to conduct seismic hazard studies. Among these were Ambato, where it was decided to do a seismic microzoning of the urban area in 2018. In these studies, two methods (probabilistic and deterministic) were used to find the spectra vs. the horizontal component of ground movement. For the last method, values were acquired from three models of strong motion, which have been called in this article Spectra 2018.

In the 2018 study, geophysical and geotechnical studies were done in different places of the city, at least one in each parish, to determine the vibration period of the soil, speed of the shear wave in the first $30 \mathrm{~m}$, number of blows in the SPT, and other parameters from which the soils were classified from a seismic perspective.

For each seismic soil profile, the 2018 Spectra were found by considering a seismic event of maximum magnitude on each of three blind faults traversing the city. In this endeavor, the recurrence period of an earthquake of maximum magnitude was first determined for each fault, using the two aforementioned methods. Results were analyzed in relation to the historical seismicity of the city, discovering that an earthquake with magnitude 6.3 can occur in the next 80 to 100 years, and one of magnitude 6.5 during the next 300 years.

In the same way, spectra were obtained using the deterministic method, but considering six models with strong motion equations, among them that of Zhao et al. (2016). These were obtained from Spectra 2020, which are very similar to those of 2018. Therefore, we decided to consider as a contribution to the studies of 2018 the spectral envelopes, the same that were compared to the spectra that would be obtained in each soil seismic profile for earthquakes of maximum magnitude on each fault, and were compared with the spectra reported in the Ecuadorian Standard of Construction (NEC-15). There was strong correlation for soil profile $\mathrm{C}$, whereas for profile $\mathrm{D}$, there was a reduction of spectral ordinates for long periods. For soil profile E, it is suggested to increase the spectrum plateau to $1.2 \mathrm{~g}$.

\section{ACKNOWLEDGMENTS}

The authors thank the anonymous reviewers for their contribution to improve the manuscript.

\section{References}

Abrahamson, N., Silva, W., \& Kamai, R. (2013). Update of the AS08 Ground Motion Prediction Equations based on the NGA-West2 Data Set. Pacific Earthquake Engineering Research Center, PEER.

Aguiar, R. (2017). No se acepta el diseño por ductilidad. Caso del Edificio Fragata que incursionó en el rango no lineal. Revista Internacional de Ingeniería de Estructuras, 22(3), 327-391.

Aguiar, R. (2018). Vulnerabilidad sísmica de Ambato [Consulting carried out for Ambato].

Aguiar, R., \& Rivas, A. (2018). Espectros de peligro sísmico uniforme para la ciudad de Ambato. In R. Aguiar, \& A. Rivas (eds.), Microzonificación sísmica de Ambato (pp. 103119). Instituto Panamericano de Geografía e Historia.

Aguiar, R., \& Zambrano, V. (2018). Relation H/T in structures of Bahía de Caráquez and the 2016 earthquake. Revista Internacional de Ingeniería de Estructuras, 23(2), 227-241.

Aguiar, R., Zevallos, M., Palacios, J., García, L., \& Menéndez, E. (2016). Reforzamiento de estructuras con disipadores de energía. Caso del terremoto del 16 de abril de 2016. Instituto Panamericano de Geografía e Historia (IPGH).

Akkar, S., Sandikkaya, M., \& Bommer, J. (2014). Empirical ground-motion models for point- and extended-source crustal earthquake scenarios in Europe and the Middle East. Bulletin of Earthquake Engineering, 12, 359-387. https://dx.doi.org/10.1007/s10518-013-9461-4

Alvarado, A., Audin, L., Nocquet, J., Lagreulet, S., Segovia, M., Font, Y., Lamarque, G., Yepes, H., Mothes, P., Rolandone, F., Jarrin, P., \& Quidelleur, X. (2014). Active tectonics in Quito, Ecuador, assessed by geomorphological studies, GPS data, and crustal seismicity. Advancing Earth and Space Science, 33, 67-83, https://doi.org/10.1002/2012TC003224

Beauval, C., Mariniere, J., Yepes, H., Audin, L., Nocquet, J., Alvarado, A., Baize, S., Aguiar, J., Singaucho, J. C., \& Jomard, H. (2018). A New Seismic Hazard Model for Ecuador. Bulletin of the Seismological Society of America, 108(3A), 1443-1464. https://doi.org/10.1785/0120170259

Boore, D., \& Atkinson, G. (2008). Ground Motion Prediction Equations for the Average Horizontal Component of PGA, PGV, and 5 \%-Damped PSA at Spectral Periods between $0.01 \mathrm{~s}$ and $10.0 \mathrm{~s}$. Earthquake Spectra, 24(1), 99-138. https:// doi.org/10.1193/1.2830434 
Campbell, K., \& Bozorgnia, Y. (2013). NGA-West2 Ground Motion Model for the Average Horizontal Components of PGA, PGV, and 5\% damped linear acceleration response spectra. Earthquake Spectra, 30(3), 1087-1115. https://doi. org/10.1193/062913EQS175M

Choiu, B., \& Youngs, R. (2014). Update of the Choiu and Youngs NGA ground motion model for average horizontal component of peak ground motion and response spectra. Earthquake Spectra, 30(3), 1117. https://doi.org/10.1193/072813EQS219M

Chunga, K., \& Mulas, F. (2018). Zonificación geológica, volcánica y sísmica. In R. Aguiar, \& A. Rivas (eds.), Microzonificación Sísmica de Ambato (pp. 120-172). Instituto Panamericano de Geografía e Historia.

Cosentino, P., Ficarra, V., \& Luzio, D. (1977). Truncated Exponential Frequency-Magnitude Relationship in Earthquake Statistics. Bulletin of the Seismological Society of America, 67(6), 1615-1623.

Eguez, A., Alvarado, A., \& Yepes, H. (2003). Database and Map of Quaternary Faults and Folds of Ecuador and its offshore regions [Open File Report]. U. S. Geological Survey.

Federal Emergency Management Agency of the U.S. Department of Homeland Security (FEMA). (2015). NEHRP Recommended seismic provisions for new buildings and other structures Volume I: Part 1 Provisions, Part 2 Commentary.

Gutenberg, B., \& Richter, F. (1944). Frequency of Earthquakes in California. Bulletin of the Seismological Society of America, 34(4), 185-188. https://doi.org/10.1785/BSSA0340040185

Leonard, M. (2010). Earthquake fault scaling: Self-consistent relating of rupture length, width average displacement and moment release. Bulletin of the Seismological
Society of America, 100(5A), 1971-1988. https://doi. org/10.1785/0120090189

NEC-15. (2015). Norma ecuatoriana de la construcción SE-DS. Cargas sísmicas. Diseño sismo resistente. NEC-SE-DS.

Rivas, A. (2014). Contribución metodológica para incorporar fallas activas en la modelización de la fuente dirigida a estimaciones de peligrosidad sísmica. Aplicación al sur de España [Ph.D. Thesis]. Universidad Politécnica de Madrid.

Wells, D., \& Coppersmith, J. (1994). New Empirical Relationship among Magnitude, Rupture Length, Rupture Width, Rupture Area, and Surface Displacement. Bulletin of the Seismological Society of America, 84(4), 974-1002.

Zhao, J., Zhang, J., Asano, A., Ohno, Y., Oouchi, T., Takahashi, T., Ogawa, H., Irikura, K., Hong, K., Somerville, P., Fukushima, Y., \& Fukushima, Y. (2006). Attenuation Relations of Strong Ground Motion in Japan Using Site Classification Based on Predominant Period. Bulletin of the Seismological Society of America, 96(3), 898-913. https://doi. org/10.1785/0120050122

Zhao, J., Zhou, S., Gao, P., Long, T., Zhang, Y., Thio, H., Lu, M., $\&$ Rhoades, A. (2015). An earthquake classification scheme adapted for Japan determined by the goodness-of-fit for ground-motion prediction equations. Bulletin of the Seismological Society of America, 105(5), 2750-2763. https:// doi.org/10.1785/0120150013

Zhao, J., Zhou, S., Zhou, J., Zhao, C., Zhang, H., Zhang, Y., Gao, P., Lan, X., Rhoades, D., Fukushima, Y., Somerville, P., \& Irikura, K. (2016). Ground-Motion Prediction Equations for Shallow Crustal and Upper-Mantle Earthquakes in Japan Using Site Class and Simple Geometric Attenuation Functions. Bulletin of the Seismological Society of America, 106(4), 1552-1569. https://doi.org/10.1785/0120150063 